\title{
Перспективи впровадження електронного рекрутингу у 3бройних Силах України
}

\author{
B'ячеслав Косевцов ${ }^{1}$ A; Григорій Тіхонов ${ }^{2}$ А; Олександр Білик ${ }^{3}$ А \\ А Національний університет оборони України імені Івана Черняховського, пр-кт Повітрофлотський 28, м. Київ, 03049, Україна
}

Received: August 1, 2021 | Revised: September 24, 2021 | Accepted: October 30, 2021

DOI: $10.33445 /$ sds.2021.11.5.1

\begin{abstract}
Анотація
Стаття присвячена дослідженню процесу впровадження електронного рекрутингу у провідних країнах світу та Збройних Силах України його використання у практичній роботі керівників військових організаційних структур з метою підвищення спроможностей ії персоналу у виконанні завдань, що стоять перед нею. Розглянуті сучасні наукові тенденції щодо визначення системи рекрутінгу та питання з підвищення його ефективності, сформовано основні проблемні аспекти питань його впровадження та оцінки. Визначено напрямки удосконалення оцінки персоналу на основі рекрутінгу, здійснено їх загальну характеристику та шляхи подальшого його розвитку.
\end{abstract}

Ключові слова: електронний рекрутинг, Інтернет, управління персоналом, підбір персоналу, військова організаційна структура.

\section{Постановка проблеми}

На сьогоднішній день традиційні інструменти рекрутингу, що застосовуються в збройних силах не дають бажаного результату та потребують значних фінансових та людських ресурсів. У сучасних умовах розвитку держави зростає зацікавленість служб персоналу та військових керівників до використання інформаційних технологій в управлінні військовою організаційною структурою, зокрема, і в управлінні персоналом. Разом 3 використанням інформаційних систем управління персоналом у військовій організаційній структурі, зростає роль Інтернету як сучасного засобу пошуку та підбору персоналу. У зв'язку 3 цим все більше набуває популярності електронний рекрутинг як інструмент підвищення ефективності процесу відбору та залучення персоналу.

\section{Аналіз останніх досліджень та публікацій}

Останні публікації щодо рекрутингу в основному пов'язані з авторами, які розглядають дану проблему для цивільних організацій, але вона характерна і для збройних сил і саме 3 питань залучення сучасних інформаційних технологій. Так, питання підбору та найму персоналу 3 використанням сучасних інформаційних технологій розглядаються в роботах таких вітчизняних та за рубіжних дослідників, як
Є. Лунев, І. Симанова, П. Капеллі, Е. Марр, С. Дейллон, Дж. Возняк та інших. Проте, не зважаючи на велику кількість науковців і практиків, що досліджували дане питання, у вітчизняній економічній літературі не приділено достатньо уваги розкриттю як сутнісних аспектів електронного рекрутингу, так і вигод від його застосування і особливо у збройних силах. у сучасній науковій літературі розглядаються класичний

\footnotetext{
${ }^{1}$ Corresponding author: д. військ. н., професор, професор кафедри, e-mail: kosevtsov@ukr.net

2 канд. війс. наук, старший науковий співробітник, начальник кафедри, e-mail: tikhonov2404@ukr.net

${ }^{3}$ здобувач наукового ступеня, e-mail: alexanderbilyk@ukr.net
} 
рекрутинг, тобто звичайний пошук спеціаліста, без обмежень джерел пошуку та засобів залучення кандидатів та електронний рекрутинг (е-рекрутинг, е-рекрутмент) - це метод пошуку персоналу за допомогою Інтернет-ресурсів.

\section{Постановка завдання}

Електронний рекрутинг вимагає визначити низку стадій процесу е-рекрутингу, а саме: залучення кандидатів; відбір кандидатів; контакти з кандидатами [2]

Процес е-рекрутингу передбачає поряд із залученням, відбором і співбесідою з ними також отримання додаткової інформації про кандидатів, підписання контракту й адаптацію нового персоналу. Серед сучасних факторів, які впливають на поширеність ерекрутингу, відносить такі: мобілізація, соціалізація, глобалізація, автоматизація рекрутингу, візуалізація, стандартизація навичок та поява агрегаторів вакансій. Вони потребують додаткових електронних ресурсів, зокрема, соціальних мереж, мобільних платформ для рекрутингу, автоматизованих систем управління персоналом.

Метою статті $\epsilon$ поглиблення сутності ерекрутингу, порівняння його з традиційними інструментами найму персоналу та визначення перспектив використання ерекрутингу у Збройних Силах України. Обгрунтування отриманих наукових результатів.

\section{Виклад основного матеріалу}

Поява в керівних документах Збройних Сил України [1] одного з напрямів кадрової політики як рекрутинг вимагає визначення його значення відносно збройних сил, історії його появи, ефективності застосування як у минулому так і сьогоденні та порядку його найбільш ефективного застосування під час практичної роботи в лавах збройних сил передових країн світу.

Рекру́тинг (від фр. recruit - “набирати”, "вербувати". Спочатку даний термін застосовувався щодо солдат, яких вербували в королівську армію (Франція). У подальшому поняття розширилося і в сучасних умовах визначається як - підбір персоналу в штат компанії, або під замовлення клієнта у випадку застосування спеціальної служби рекрутингового агентства. Також даний термін $€$ основною функцією і обов'язком менеджерів по персоналу та так званих рекрутерів.

На даний час рекрутинг - обов'язковий та необхідний процес у кожній організації будьякої сфери діяльності: від якості та ефективності даного процесу напряму залежить їі ефективність та фінансова результативність.

Рекрутинг у збройних силах був широко застосований у країнах західної Європи та
США. Розвиток рекрутинга найбільш яскраво можливо роздивитися на прикладі США. Набір в армію США розпочався у 1775 році 3 виховання та навчання чоловіків континенту для участі у Війні за незалежність. Створення Командування, що виконувало функції рекрутингу, почало свою історію з 1882 року з створення Генеральної служби набору. На протязі більшої частини XIX століття вербовка залишалася на рівні полкових рекрутингових партій, за звичай проводячи вербовку у свої регіонах, як це було у Європі.

До початку Громадянської війни у США існувало два типи сил, які самі проводили вербовку: для регулярної федеральної служби та для державної служби міліції.

За наявності гострої нестачі військ після першого року війни Союз та Конфедерація ввели призов на військову службу, з метою отримати можливість проводити операції на фронті майже в тисячу міль. Призив уперше був введений на Півдні. У подальшому він також був введений і на Півночі.

По закінченні Громадянської війни громадськість зрозуміла те що у подальшому неможливо спиратися лише на добровольців у відношенні до військової служби, і було зрозуміло у післявоєнному аналізі, але залежність від них продовжувалася до 
початку Першої світової війни. У той час правлячі кола США вважали, що виключення США 3 війни у Європі дозволить знайти достатню кількість добровольців для задоволення військових потреб держави. Між тим досвід європейської війни змусив у 1917 році прийняти Закон о вибірковій службі. Даний закон був дуже вибірковим та змушував призивати в армію некваліфіковану робочу силі та неодружених юнаків. Так внаслідок цього в армію було призвано $90 \%$ неодружених, а $70 \%$ складали сільхозробітники.

Призов знов був використаний для створення армії воєнного часу з невеликої кількості професійних кадрів мирного часу у 1941 році, яка наприкінці війни налічувала 8,3 мільйона чоловік. Потрібно підкреслити, що під час Другої світової війни призов на військову службу підтримувався широким прошарком громади. Дія даного Закону була закінчена 31 березня 1947 року та армія знову перейшла на залучення добровольців, для чого за розрахунками потрібно було 30000 добровольців у місяць. А вдавалося залучити лише 12000 чоловік.

3 початком Холодної війни та війни у Кореї були переглянуті закони щодо залучення на військову службу. Новий закон поширював права Президента по можливому залученню на службу до 4 років, надавав йому право відзивати резервістів, зменшив призивний вік до 18 років, збільшив термін служби до 2 років та відмінив відстрочки для одружених чоловіків без дітей.

По закінченню Корейської війни даний закон залишався в дії але був вкрай непопулярним. Під тиском громадськості його відміна відбулася у 1973 році. 3 того часу армія США стала знову повністю добровольчою. Лозунгом США з цього часу стали слова Президента: “Ми разом вважаємо, що інтереси нації будуть краще обслуговуватися силами, що повністю складаються з добровольців, при підтримці ефективного резервного призову, ніж при допомозі змішаних сил добровольців та призовників; ці шаги повинні бути проведені негайно, щоб рухатися в цьому напрямі".
Сприяючи даному переходу до повністю добровольчої армії, у США були створені вербувальні команди (DRC) по усій території країни та мали форму рекрутингових центрів. У 1983 році DRC стали “Батальйонами".

Усього USAREC (командування рекрутингу) складається з восьми бригад: п'ять призовних та залучення до служби, одна медична рекрутингова та дві рекрутингові допоміжні бригади. Кожна призовна та медична медична бригада складається з декількох батальйонів, кожний батальйон складається 3 чотирьох-сьоми рот. Кожним батальйоном командує підполковник, в його штаті 12 офіцерів, 20 цивільних співробітників та 250 рядових солдатів, більшість з них працюють у якості рекрутерів на виробництві, та виконують основну частину місії USAREC щодо надання підтримки у наборі персоналу в офісах по усій території США та інших країнах.

Таким чином, можливо констатувати, що в США історично склалася досить потужна система рекрутингового комплектування збройних сил добровольцями, яка дозволяє мати достатню кількість якісного персоналу, що забезпечує високу боєздатність збройних сил в мирний час. Разом з тим досвід показує, що під час значних збройних конфліктів США поверталися до призову. Призов мав в основному вибірковий характер при якому до лав збройних сил залучався контингент найменше потрібних на промисловому виробництві осіб.

Для Збройних Сил України створення рекрутингу буде проводитися на базі територіальних центрів комплектування та соціальної підтримки. їх завданням буде широко застосовуючи джерела людських ресурсів проводити спрямовану політику щодо набору найбільш якісного персоналу. Зазначений персонал контингент буде залучатися використовуючи різноманітні джерела інформації, а саме:

внутрішню базу установ або агенцій по найму;

сайти по пошуку роботи;

так званий соціальний капітал (або пошук кандидатів по знайомству); 
3MI;

соціальні мережі, форуми, блоги та ін.;

ВН3, тобто залучення молодих спеціалістів

з вищих навчальних закладів;

співпраця з цивільними рекрутинговими агенціями.

Рекрутинг умовно поділяється на кілька видів:

Хедхантинг - або переманювання співробітників інших компаній (як правило у конкурентів). У випадку замовлення в рекрутинговому агентстві - це найдорожча послуга. Для збройних сил це звичайний спосіб призначити якісного командира на іншу військову частину всупереч бажання командира якому підлеглий цей офіцер.

Масовий набір персоналу. В збройних силах він характерний при початку бойових дій і буде відбуватися в основному шляхом призову.

Сьогодні використання Інтернету у суспільстві та економіці держави $\epsilon$ невід'ємною частиною як суспільного, так і професійного життя. Доволі часто Інтернет розглядається як інструмент найму персоналу. Цей процес поширюється по всьому світу як засіб пошуку роботи та найму [2, с. 82]. Внаслідок цього і виник термін електронний рекрутинг (е-рекрутинг, ерекрутмент), який ще використовують як онлайн-рекрутмент чи Інтернет-рекрутмент.

Як стверджує Возняк Дж. в роботі [2], ерекрутмент - це одна зі швидкозростаючих областей сучасного рекрутменту. Його використання зростає по мірі того, як зростає кількість Інтернет-користувачів, тобто розширюється доступ до мережі серед потенційних роботодавців та працівників.

У літературі визначається, що ерекрутмент - це використання Інтернету 3 метою пошуку кандидатів, відбору, спілкування і управління під час всього процесу рекрутингу [5, с. 53].

Дослідження підходів різних авторів щодо поняття “електронний рекрутмент" дозволило дійти висновку, що:

на сьогодні не існує єдиного підходу до визначення цього поняття;

використання інформаційних технологій або Інтернету - це видова ознака поняття

електронного рекрутменту;

в основному вважається, що е-рекрутмент $\epsilon$ тільки процесом пошуку або ж пошуку та відбору кандидатів, проте на сьогодні можливості е-рекрутменту значно ширші i дозволяють повністю реалізувати процес найму. Так, взагалі під е-рекрутментом розуміється інструмент управління персоналом, який передбачає використання сучасних інформаційних технологій з метою оптимізації процесу рекрутингу та підвищення ефективності управління персоналом на підприємстві так і у Збройних Силах України.

У своєму дослідженні Марр Е. [5, с. 54] зазначає, що 75 \% менеджерів з персоналу використовують методи електронного рекрутменту разом з традиційними методами пошуку та підбору персоналу (газети, об'яви, рекомендації тощо). При цьому, за дослідженнями сайту rabota.ua [8] 30 \% претендентів користуються Інтернетом для пошуку роботи. Досвід показує, даний процес має свої переваги та недоліки, що дозволяє окреслити коло можливостей й відповідно проблем і труднощів, з якими може зіштовхнутись служба персоналу військової організаційної структури при використанні е-рекрутменту в процесі управління персоналом.

Аналіз робіт Капсе А., Дейллон С., Марр Е., Каппеллі П., Симанової І. та Лунева $€$. $[2 ; 4 ; 5$; 9; 10; 11] дозволив виявити переваги та недоліки е-рекрутменту в порівнянні 3 традиційними інструментами найму персоналу.

Переваги та недоліки використання ерекрутменту наведені у табл. 1.

Наведені переваги і недоліки дозволяють окреслити коло можливостей й відповідно проблем і труднощів, з якими може зіштовхнутись військова організаційна структура при використанні е-рекрутменту в процесі управління персоналом.

Каппеллі П. [9] виділяє такі стадії процесу е-рекрутменту:

залучення кандидатів;

відбір кандидатів; 
контакти з кандидатами.

Проте на сьогодні е-рекрутмент передбачає поряд із залученням, відбором кандидатів і співбесідою з ними також отримання додаткової інформації про кандидатів, підписання контракту й адаптацію нових працівників. Тому доцільно до запропонованого переліку стадій додати ще дві стадії - підписання контракту та адаптація співробітника.

\section{Таблиця 1 - Основні переваги і недоліки е-рекрутменту}

\begin{tabular}{|c|c|}
\hline Переваги & Недоліки \\
\hline $\begin{array}{l}\text { Низькі витрати у порівнянні з розміщенням } \\
\text { вакансії у зМІ }\end{array}$ & $\begin{array}{l}\text { Проблеми і значні витрати часу, пов'язані } 3 \\
\text { перевіркою достовірності даних резюме та їх } \\
\text { відповідність “паспорту посади” }\end{array}$ \\
\hline Скорочення витрат часу на пошук & Не інформативність резюме \\
\hline $\begin{array}{l}\text { Обмін інформацією між роботодавцем і } \\
\text { здобувачем здійснюється оперативно і без } \\
\text { посередника }\end{array}$ & $\begin{array}{l}\text { Необхідність комбінування } 3 \text { традиційними } \\
\text { методами рекрутменту }\end{array}$ \\
\hline $\begin{array}{l}\text { Сприяння відбору правильного типу людей з } \\
\text { потрібними знаннями і навичками }\end{array}$ & $\begin{array}{l}\text { Надання роботодавцями переваги особистим } \\
\text { контактам із здобувачами }\end{array}$ \\
\hline $\begin{array}{l}\text { Покращення загальної ефективності процесу } \\
\text { найму персоналу }\end{array}$ & Відсутність ряду категорій спеціалістів у Інтернет \\
\hline Цілодобовий доступ до великої бази резюме & $\begin{array}{l}\text { Неструктурованість баз даних і, як наслідок, не } \\
\text { завжди ефективний пошук }\end{array}$ \\
\hline $\begin{array}{l}\text { Автоматичне } \\
\text { кандидатів }\end{array}$ & $\begin{array}{llcl}\text { Хвилювання } & \text { здобувачів } & 3 & \text { приводу } \\
\text { конфіденційності розміщеної інформації } & \\
\end{array}$ \\
\hline Миттєва відповідь на об'яву про вакансію. & $\begin{array}{l}\text { Виключення дискримінації претендентів за будь- } \\
\text { якою ознакою при розробці тестових програм і } \\
\text { опитувань он-лайн }\end{array}$ \\
\hline $\begin{array}{l}\text { Доступ до цінної інформації про стан і } \\
\text { тенденції ринку праці, рівень заробітних плат } \\
\text { тощо }\end{array}$ & $\begin{array}{l}\text { Обмеженість аудиторії через відсутність у деякої } \\
\text { категорії людей доступу до Інтернет, комп'ютерної } \\
\text { грамотності }\end{array}$ \\
\hline Нівелювання географічних меж & $\begin{array}{l}\text { Необхідність певного досвіду для успішного } \\
\text { пошуку кандидатів в мережі Інтернет }\end{array}$ \\
\hline Ідентифікація пасивних пошукувачів роботи & Обов’язковий доступ до мережі Інтернет \\
\hline $\begin{array}{l}\text { Зниження завантаженості менеджерів } 3 \\
\text { персоналу адміністративною роботою }\end{array}$ & - \\
\hline $\begin{array}{l}\text { Додаткова можливість просування самого } \\
\text { підприємства-роботодавця }\end{array}$ & - \\
\hline
\end{tabular}

Джерело: узагальнено автором на основі $[2 ; 4 ; 5 ; 9 ; 10 ; 11]$

Слід зазначити, що переваги ерекрутменту не відсікають використання традиційних інструментів найму персоналу, а навпаки, разом з недоліками свідчать про необхідність комплексного використання обох груп методів.

Крім того, в сучасних умовах використання е-рекрутменту вітчизняними організаціями знаходиться під впливом факторів. До основних тенденції, що впливають на використання е-ректрутменту, Облов А. в роботі [12] відносить такі: мобілізація, соціалізація, глобалізація, автоматизація рекрутингу, візуалізація, стандартизація навичок та поява агрегаторів вакансій. Всі ці тенденції підвищують роль електронного рекрутменту та вимагають від організації розширення функцій е-рекрутменту, а саме, залучення соціальних мереж, використання мобільних платформ для рекрутменту, впровадження та застосування автоматизованих систем управління персоналом, розширення географічних меж пошуку претендентів. 


\section{Висновки}

У наслідок проведеного дослідження було виявлено, що у сучасних умовах рекрутинг $\epsilon$ основним способом залучення персоналу до лав збройних сил у передових країнах світу. Хоча 3 виникненням потужних військових конфліктів виникає необхідність введення призову.

Було уточнено та поглиблено визначення ерекрутменту щодо використання у Збройних Силах України, проаналізовано переваги i недоліки використання організацією ерекрутменту, висвітлено сучасні тенденції його використання.

Слід зазначити, що е-рекрутмент - це відмінний спосіб подолати географічні відстані, заощадити час і здобути необхідну інформацію, що на $30 \% €$ запорукою успіху у вирішенні завдань з пошуку необхідного працівника. До того ж створення єдиної бази військовозобов'язаних може значно прискорити процес призову у випадку його впровадження.

Водночас стратегія і тактика найму персоналу визначається потребами збройних сил, а не можливостями спеціальних сайтів. Тому для підвищення ефективності управління персоналом слід враховувати сучасні тенденції та комбінувати традиційні та електронні інструменти що зараз застосовуються у Збройних Силах України.

\section{Список використаних джерел}

1. Про затвердження основних напрямів розвитку військової кадрової політики у Збройних Силах України на період до 2025 року: наказ Міністерства оборони України від 12.01.2021 № $5 . \quad$ URL: https://www.mil.gov.ua/content/mou_orders /mou_2021/5_nm.pdf [дата зверн.: 03.08.2021].

2. Avinash S. Kapse. E-recruitment / Avinash S. Kapse, Vishal S. Patil, Nikhil V. Patil. // International Journal of Engineering and Advanced Technology. - 2012. - Volume 1, Issue 4. pp. 82-86.

3. Wozniak J. On e-recruitment and four ways of using its methods / J. Wozniak // 8th International Scientific Conference "Business and Management 2014" May 15-16, 2014, Vilnius, Lithuania. - pp. 691-699.

4. Deillon $C$. The advantages and challenges of turning towards e-recruitment for small and medium sized businesses / C. Deillon. Fribourg: University of Fribourg, 2013. 39 p.

5. Marr E. E-recruitment: the effectiveness of the Internet as a recruitment sourse / E. Marr. Brisbane: Queensland University of Technology, 2007. 185 p.

6. Suvankulov F. Job search on the Internet, erecruitment, and labour market outcomes / F. Savankulov. - Santa Monica: RAND Corporation, 2010. 143 p.
7. Othman R. E-recruitment practice: pros vs. cons / R. Othman, N. Musa // Public Sector ICT Management Review. - 2006. - Volume 1, No. 1. pp. 35-40.

8. Інтерент-портал Rabota.ua. [Електронний pecypc]. URL:: http://rabota.ua/. [дата зверн.: 03.08.2021].

9. Cappelli P. Making the Most of on-Line Recruiting / P. Cappelli // Harvard Business Review, 2001. - 79 (3). pp. 139-146.

10. Симанова И. "Реальный” рекрутинг и интернет-рекрутинг: за и против / И. Симанова. [Электронный ресурс]. URL: http:// aviconn.com/press/ realniyrecruting.html. [дата зверн.: 03.08.2021].

11. Лунев Е. А. Информационные технологии в управлении персоналом: Учебнометодический комплекс / Е. А. Лунев. Москва: Центр дистанционных образовательных технологий, 2010. URL: http://www.e-college.ru/xbooks/xbook106/ book/index/index.html?go=index*title.htm. [дата зверн.: 03.08.2021].

12. Облов А. 7 глобальных трендов, которые перевернут онлайн-рекрутмент / А. Облов // Ведомости. - 2015. [Электронный ресурс]. URL: $\quad$ https://www.vedomosti.ru/ management/blogs/2015/08/03/603239internet-rekrutment. [дата зверн.: 03.08.2021]. 


\title{
Перспективы внедрения электронного рекрутинга в Вооруженных Силах Украины
}

\author{
Вячеслав Косевцов * 1 А; Григорий Тихонов 2 А; Александр Билык 3 А \\ Corresponding author: ${ }^{1}$ д.в.н., професор, профессор кафедры, e-mail: kosevtsov@ukr.net \\ 2 канд. воен. наук, старший научный сотрудник, начальник кафедры, e-mail: tikhonov2404@ukr.net \\ ${ }^{3}$ Соискатель ученой степени, e-mail: alexanderbilyk@ukr.net \\ А Национальный университет обороны Украины имени Ивана Черняховского, пр-кт Воздухофлотский, 28 г. Киев, 03049, Украина
}

\section{Аннотация}

Статья посвящена исследованию процесса внедрения электронного рекрутинга в ведущих странах мира и Вооруженных Силах Украины его использования в практической работе руководителей военных организационных структур с целью повышения возможностей ее персонала в выполнении задач, стоящих перед ней. Рассмотрены современные научные тенденции определения системы рекрутинга и вопросы по повышению его эффективности, сформированы основные проблемные аспекты вопросов его внедрения и оценки. Определены направления совершенствования оценки персонала на основе рекрутинга, осуществлено их общую характеристику и пути дальнейшего его развития.

Ключевые слова: электронный рекрутинг, Интернет, управление персоналом, подбор персонала, военная организационная структура.

\section{Prospects for the introduction of electronic recruitment in the Armed Forces of Ukraine}

\author{
Vyacheslav Kosevtsov * 1 A; Grigory Tikhonov 2 A; Aleksandr Bilyk 3 A \\ Corresponding author: ${ }^{1} \mathrm{Dr}$ of military sciences, professor, professor department, e-mail: kosevtsov@ukr.net \\ ${ }^{2}$ Candidate of Military Sciences, Senior Researcher, Chief of Department, e-mail: tikhonov2404@ukr.net \\ ${ }^{3}$ Applicant for a scientific degree, e-mail: alexanderbilyk@ukr.net \\ A National Defence University of Ukraine named after Ivan Cherniachovskyi, 28, Povitroflotsky, ave, Kyiv, 03049, Ukraine
}

\begin{abstract}
The article is devoted to the study of the process of introducing electronic recruiting in the leading countries of the world and the Armed Forces of Ukraine of its use in the practical work of the heads of military organizational structures in order to increase the capabilities of its personnel in performing the tasks facing it. The modern scientific trends in the definition of the recruiting system and the issues of increasing its efficiency are considered, the main problematic aspects of the issues of its implementation and evaluation are formed. The directions for improving the assessment of personnel on the basis of recruiting have been determined, their general characteristics and ways of its further development have been carried out.
\end{abstract}

Keywords: electronic recruiting, Internet, personnel management, personnel selection, military organizational structure.

\section{References}

1. Pro zatverdzhennia osnovnykh napriamiv rozvytku viiskovoi kadrovoi polityky u Zbroinykh Sylakh Ukrainy na period do 2025 roku [On approval of the main directions of development of military personnel policy in the Armed Forces of Ukraine for the period up to 2025]: nakaz Ministerstva oborony Ukrainy vid 12.01.2021 № 5. Available from: https://www.mil.gov.ua/content/mou_orde rs/mou_2021/5_nm.pdf [Accessed: 03.08.2021].

2. Avinash S. Kapse. E-recruitment / Avinash S. 
Kapse, Vishal S. Patil, Nikhil V. Patil. // International Journal of Engineering and Advanced Technology. - 2012. - Volume 1, Issue 4. - pp. 82-86.

3. Wozniak J. On e-recruitment and four ways of using its methods / J. Wozniak // 8th International Scientific Conference "Business and Management 2014" May 15-16, 2014, Vilnius, Lithuania. - pp. 691-699.

4. Deillon C. The advantages and challenges of turning towards e-recruitment for small and medium sized businesses / C. Deillon. Fribourg: University of Fribourg, 2013. 39 p.

5. Marr E. E-recruitment: the effectiveness of the Internet as a recruitment sourse / E. Marr. - Brisbane: Queensland University of Technology, 2007. - 185 p.

6. Suvankulov F. Job search on the Internet, erecruitment, and labour market outcomes / F. Savankulov. - Santa Monica: RAND Corporation, 2010. 143 p.

7. Othman R. E-recruitment practice: pros vs. cons / R. Othman, N. Musa // Public Sector ICT Management Review. - 2006. Volume 1, No. 1. - pp. 35-40.

8. Інтерент-портал Rabota.ua. Available from: http://rabota.ua/. [дата зверн.: 03.08.2021].

9. Cappelli P. Making the Most of on-Line Recruiting / P. Cappelli // Harvard Business Review, 2001. - 79 (3). pp. 139-146.

10. Symanova Y. "Realnyi" rekrutynh y ynternet-rekrutynh: za y protyv ["Real" recruiting and online recruiting: pros and cons]. Available from: http:// aviconn.com/press/ realniy-recruting.html. [Accessed: 03.08.2021].

11. Lunev E. A. Ynformatsyonnye tekhnolohyy v upravlenyy personalom: Uchebnometodycheskyi kompleks [Information technologies in personnel management: Educational-methodical complex.]. Available from: http://www.e-college.ru/xbooks/ xbook106/book/index/index.html?go=index *title.htm. [Accessed: 03.08.2021].

12. Oblov A. (2015) 7 global'nykh trendov, kotoryye perevernut onlayn-rekrutment [Global Trends That Will Turn Online Recruitment]/ Available from: https://www.vedomosti.ru/management/ blogs/2015/08/03/603239-internet-rek. [Accessed: 03.08.2021]. 